\title{
KULIT JAGUNG UNTUK PEMBUATAN KERTAS KEMASAN DENGAN PROSES HIDROTERMAL DENGAN METODE SODA
}

Rachmawati Apriani $^{1 *}$, Nurul Ajeng Susilo ${ }^{1}$, Frans Ferdinand ${ }^{1}$, Iyas Majita ${ }^{1}$, Early Mahardhika ${ }^{1}$, Erlita Kusuma Wardhani ${ }^{1}$, Alby Venrian ${ }^{1}$

${ }^{1}$ Teknologi Pengolahan Pulp dan Kertas, Fakultas Vokasi, Institut Teknologi dan Sains Bandung, Bekasi, Jawa Barat

Email korespondensi: rachmawatiapriani46@gmail.com

\begin{abstract}
Abstrak. Kulit jagung (Zea mays ssp. mays) merupakan bagian tanaman yang melindungi biji jagung. Limbah kulit jagung sudah digunakan sebagai pakan ternak oleh masyarakat, akan tetapi pemanfaatannya belum maksimal. Limbah tersebut masih memiliki nilai ekonomis yang rendah dan dapat menimbulkan pencemaran lingkungan saat dibakar. Kulit jagung memiliki kandungan serat selulosa yang tinggi, sehingga dapat dimanfaatkan sebagai bahan baku pembuatan kertas. Penelitian ini bertujuan mencari alternatif bahan baku non kayu untuk kertas kemasan. Kemasan kertas merupakan kemasan fleksibel yang pertama sebelum ditemukannya plastik dan aluminium foil. Hingga saat ini, kemasan kertas masih banyak digunakan dan mampu bersaing dengan kemasan lain seperti plastik dan logam karena harganya murah, mudah diperoleh dan penggunaannya yang luas. Tujuan penelitian ini untuk mengetahui perbedaan proses penetrasi larutan pemasak ke chip dengan proses pretreatment hidrotermal atau tidak sebelum proses pembuatan pulp melalui proses pemasakan dengan soda panas, untuk mengetahui properties strength berupa kekuatan Tarik, kekakuan taber, derajat kecerahan, daya Serap Air (Cobb $60^{*}$ ) dari kertas kemasan berbahan dasar kulit jagung dengan penambahan $\mathrm{NaOH}$ dengan proses hidrotermal. Penelitian ini menggunakan metode pemasakan dengan soda panas dengan menggunakan proses pretreatment hidrotermal dengan memvariasikan suhu proses dan waktu tunggu proses pretreatment hidrotermal, suhu dan waktu proses pulping. Semakin besar suhu dan tekanan maka terjadi kenaikan terhadap nilai $\mathrm{pH}$ pada $5 \% \mathrm{NaOH}$ dan $5 \% \mathrm{NaOH}$ dengan pretreatment. Semakin besar suhu dan tekanan maka terjadi penurunan terhadap massa padatan pada $5 \% \mathrm{NaOH}$ dan $5 \% \mathrm{NaOH}$ dengan pretreatment. Semakin besar tekanan dan suhu maka terjadi peningkatan terhadap nilai konsistensi pada $5 \% \mathrm{NaOH}$. Semakin besar tekanan dan suhu maka terjadi peningkatan terhadap nilai massa padatan pada $5 \% \mathrm{NaOH}$ tanpa pretreatment.
\end{abstract}

Kata kunci: kulit jagung, hidrotermal,kertas kemasan 


\section{Pendahuluan}

Kulit jagung merupakan bagian tanaman yang melindungi biji jagung. Limbah kulit jagung sudah digunakan sebagai pakan ternak oleh masyarakat, akan tetapi pemanfaatannya belum maksimal. Limbah tersebut masih memiliki nilai ekonomis yang rendah dan akan menimbulkan pencemaran lingkungan saat dibakar. Kulit jagung memiliki kandungan serat selulosa yang tinggi, sehingga dapat dimanfaatkan sebagai bahan baku pembuatan kertas. Fagbemigun (2014), komposisi kimia kulit jagung meliputi $15 \%$ lignin; 5,09\% abu; 4,57\% alkoholsikloheksana; dan $44,08 \%$ selulosa. Septiningrum (2011), hasil analisis kimia dari tongkol jagung mengandung hemiselulosa $30,91 \%$; alfa selulosa $26,81 \%$; lignin $15,52 \%$; karbon $39,80 \%$; nitrogen $2,12 \%$; dan kadar air $8,38 \%$. Ningsih (2012), proses pembuatan pulp dapat menggunakan bahan baku non kayu, salah satunya yaitu limbah pertanian kulit jagung. Penelitian Daniatri (2015), pembuatan pulp dari bulu ayam dan kulit jagung, menghasilkan kertas seni dengan kekuatan tarik tertinggi $8,8410 \mathrm{~N}$ dan kekuatan sobek tertinggi 22,0088 N. Hasil penelitian Indriany (2013), limbah tongkol jagung dengan penambahan sel ragi amobil menghasilkan bioetanol. Diperoleh rasio asam sulfat $50 \%$ terhadap tepung tongkol jagung yang baik diterapkan untuk proses hidrolisis sellulosa tepung tongkol jagung adalah pada rasio $5: 1(\mathrm{v} / \mathrm{b})$ menghasilkan kadar gula total sebesar $41,63 \%$. Kertas merupakan bahan tipis berbentuk lembaran yang sering digunakan oleh masyarakat seperti membungkus, kerajinan, dan sebagainya. Jenis kertas yang meliputi kertas HVS, kertas buram, kertas buffalo, kertas tisu, kertas minyak, dan kertas seni (art paper). Fungsi plastik sebagai pembungkus/kemasan yang mulai dikurangi menyebabkan beralihnya ke kemasan dengan bahan kertas. Kertas kemasan Kemasan kertas merupakan kemasan fleksibel yang pertama sebelum ditemukannya plastik dan aluminium foil. Hingga saat ini, kemasan kertas masih banyak digunakan dan mampu bersaing dengan kemasan lain seperti plastik dan logam karena harganya murah, mudah diperoleh dan penggunaannya yang luas. Kemasan memainkan peranan penting untuk melindungi barang dari berbagai kerusakan. Kertas merupakan salah satu bahan yang digunakan untuk membuat kemasan. Setiap jenis kemasan memiliki fungsi dan tujuan yang berbeda-beda, tergantung jenis barang yang akan dikemas. Selain dari segi harga yang tidak mahal, kemasan kertas dapat digunakan sebagai media komunikasi dan promosi suatu produk.

Pada penelitian sebelumnya oleh Sanastri (2014) diproduksi kertas seni (art paper) dengan tekstur agak kasar dan seratnya terlihat sehingga menghasilkan tekstur yang tidak merata dengan bahan baku menggunakan kulit jagung dengan tongkol jagung sehingga menghasilkan kertas seni dengan tekstur kasar dan seratnya nampak.Bahan tambahan yang digunakan yaitu larutan pemasak $(\mathrm{NaOH})$, sebelumnya ditambahkan perekat (lem PVAc), pengawet alami (garam), dan pewarna alami (daun jati).

Menurut Fajriani (2010), pada pembuatan kertas seni untuk mengikat komponen antar serat pada proses pembentukan lembaran diperlukan penambahan bahan perekat sehingga serat dapat membentuk lembaran kertas yang kuat. Pada penelitian sebelumnya bahan perekat yang digunakan adalah perekat PVAc (Polyvinyl acetate). Mustafa (2006), menyebutkan bahwa garam merupakan zat pengawet organik yang digunakan sebagai salah satu metode pengawetan pangan yang pertama dan masih digunakan secara luas untuk mengawetkan. Menurut Ati (2006), daun jati muda mengandung pigmen alami antosianin. Moldovan (2012), menambahkan bahwa warna cerah antosianin berpotensi sebagai pewarna alami untuk menggantikan pewarna buatan. Pujiarti (2006), membuat ekstrak daun jati sebagai pewarna alami batik. Filtrar terbaik yaitu ekstrak daun jati muda pada konsentrasi 1 : 10 .

Sucipto (2009), menjelaskan bahwa pada pembuatan kertas seni penambahan larutan $\mathrm{NaOH}$ berfungsi untuk melarutkan lignin saat proses pembuburan (pulping) sehingga mempercepat proses pemisahan dan pemutusan serat.

Menurut (Prasetyawati, Dwi Putri.2015) dalam pemanfaatan kulit jagung dan jongkol Jagung (Zea mays) sebagai bahan dasar pembuatan kertas seni dengan penambahan Natrium Hidroksida $(\mathrm{NaOH})$ dan pewarna alami menghasilkan kertas dengan kekuatan tarik dan kekuatan sobek paling tinggi pada perlakuan A3B3 (75g kulit jagung $+25 \mathrm{~g}$ tongkol jagung + $50 \mathrm{~g}$ daun jati) $13,7116 \mathrm{~N}$. Kertas seni dengan kekuatan tarik paling rendah pada perlakuan A2B3 (25g kulit jagung $+75 \mathrm{~g}$ tongkol jagung + $50 \mathrm{~g}$ daun jati) $6,9821 \mathrm{~N}$. Kertas seni dengan 
kekuatan sobek paling rendah pada perlakuan A2B1 (25g kulit jagung $+75 \mathrm{~g}$ tongkol jagung tanpa daun jati) 7,6681 N. Kertas seni yang banyak disukai masyarakat yaitu perlakuan A3B1 (warna kuning / cerah, serat tidak nampak, tekstur sangat halus) dan perlakuan A3B3 (warna coklat tua / tegas, serat nampak, tekstur kasar).

Penellitian ini keterbaruannya mulai dari bahan baku untuk pembuatan pulp yaitu bahan baku non kayu yang berupa kulit jagung dan menggunakan proses pretreatment hidrotermal. Proses pretreatment hidotermal bertujuan untuk mempermudah masuknya larutan pemasak / liquor kedalam kulit jagung sehingga mempercepat proses pemasak (pulping)

\section{Metode}

Penyiapan Bahan

1. Kulit jagung dipotong kecil membentuk chip

2. Hasil potongan kemudian dikeringkan menggunakan sinar matahari dan udara sekitar.

Proses Hidrotermal

1. Chip kulit jagung dengan beberapa macam ukuran dicampur dengan air dengan perbandingan sesuai variabel percobaan di dalam reaktor.

2. Memanaskan reaktor pada suhu, waktu sesuai variabel.

3. Setelah proses hidrolisis, solid dipisahkan dengan disaring.

4. Sebagian dari solid dan liquid hasil proses dianalisa.

Proses Pulping

1. Proses pulping dilakukan pada reaktor yang sama dengan yang digunakan pada proses hidrotermal.

2. Cairan pemasak terdiri dari cairan pemasak dengan Natrium Hidroksida dengan konsentrasi sesuai dengan variable.

3. Solid hasil hidrotermal dimasukkan dalam reaktor dan dicampur dengan cairan pemasak (jenis dan perbandingan sesuai dengan variabel).

4. Dilakukan proses pulping dengan kondisi operasi (suhu, to time dan lama proses) sesuai dengan variabel.

5. Setelah proses pulping, solid dan liquid dipisah menggunakan penyaring untuk dianalisa.

\section{Metode Analisis}

Pulp dianalisis

1. Menghitung \% Yield untuk mengetahui jumlah pulp yang dihasilkan terhadap bahan baku.

2. Mengukur Kappa number untuk mengetahui jumlah lignin yang terurai

3. Mengukur Brightness untuk mengetahui derajat kecerahan pulp yang dihasilkan.

4. Menghitung Runkl Number untuk mengetahui tebal dinding serat yang berkaitan dengan efektivitas difusi liquor.

5. Mengukur Tensile strength untuk mengetahui kekuatan tarik kertas dari pulp yang dihasilkan.

6. Pengujian kekakuan taber dinyatakan sebagai momen lengkung atau ketahanan lengkung.

7. Pengujian elongation yang merupakan pengujian mekanikal pemeluran suatu benda

8. Mengukur Thickness /ketebalan. Mengukur daya serap air (cobb) untuk menjaga penetrasi cairan tidak berlebihan.

\section{Hasil dan Pembahasan}

\section{Data Hasil Percobaan}

Tabel 1. Hubungan antara suhu terhadap $\mathrm{pH}$ dan massa padatan

\begin{tabular}{|l|c|c|c|c|c|c|}
\hline & \multicolumn{3}{|c|}{$5 \% \mathrm{NaOH}$} & \multicolumn{3}{c|}{$5 \% \mathrm{NaOH}$ (Pretreatment) } \\
\hline & 130 & 140 & 150 & 130 & 140 & 150 \\
\hline $\begin{array}{l}\text { Massa } \\
\text { padatan }\end{array}$ & 1164 & 1280 & 1030 & 1146,3 & 1141,65 & 1071,7 \\
\hline $\mathrm{pH}$ & 5 & 6 & 5 & 4 & 6 & 7 \\
\hline
\end{tabular}

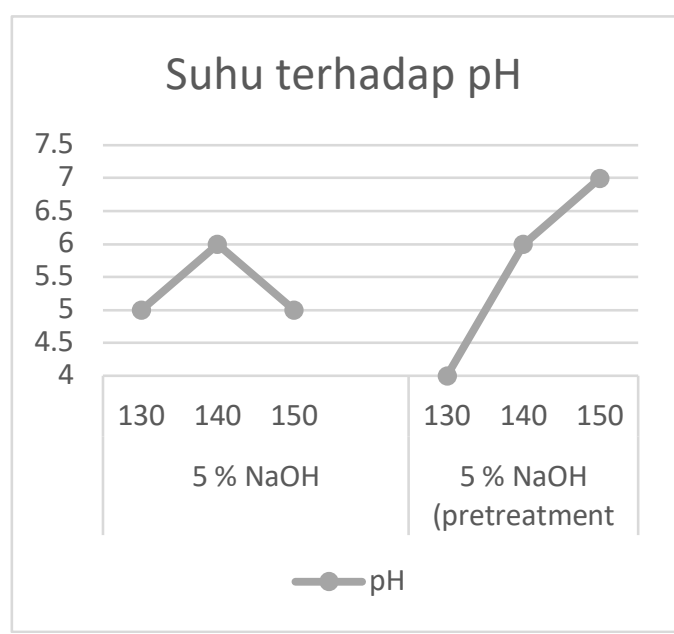

Gambar 1. Hubungan suhu terhadap $\mathrm{pH}$ 
Semakin besar suhu maka terjadi kenaikan terhadap nilai $\mathrm{pH}$ pada $5 \% \mathrm{NaOH}$ dan $5 \%$ $\mathrm{NaOH}$ dengan pretreatment.

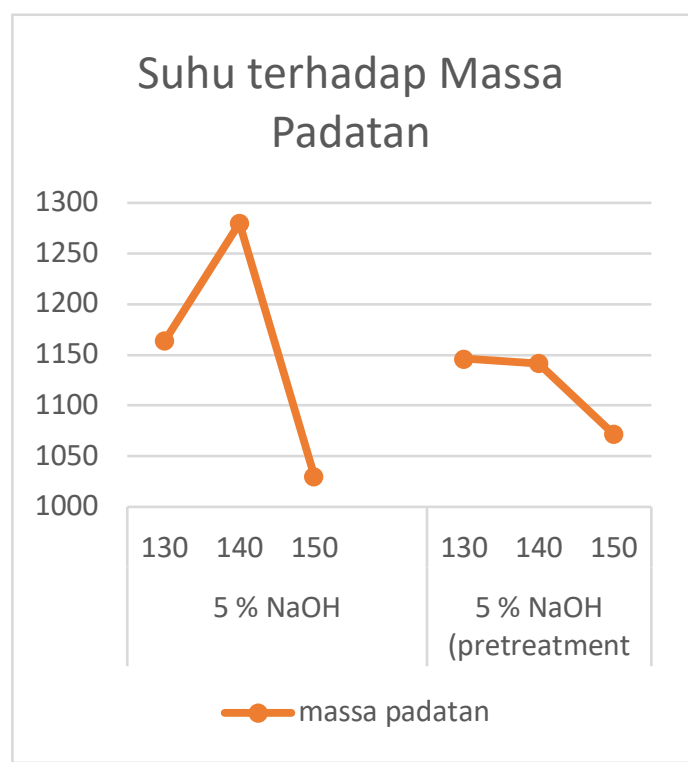

Gambar 2. Hubungan suhu terhadap massa padatan

Kandungan lignin yang harus dihilangkan memiliki batas suhu terdegradasi $170^{\circ} \mathrm{C}$ dan selulosa terdegradasi pada $120^{\circ} \mathrm{C}$. Dari grafik diatas untuk kulit jagung dengan suhu $140^{\circ} \mathrm{C}$ dan $5 \% \mathrm{NaOH}$ mampu menahan degradasi selulosa yang banyak tetapi sudah mampu mengurangi kandungan lignin sehingga menghasilkan padatan (yield dan rendemen pulp) yang lebih banyak.

Semakin besar suhu maka terjadi penurunan terhadap massa padatan pada $5 \% \mathrm{NaOH}$ dan $5 \%$ $\mathrm{NaOH}$ dengan pretreatment

Tabel 2. Hubungan antara tekanan terhadap $\mathrm{pH}$ dan massa padatan

\begin{tabular}{|l|c|c|c|c|c|c|}
\hline & \multicolumn{3}{|c|}{$5 \% \mathrm{NaOH}$} & \multicolumn{3}{c|}{$5 \% \mathrm{NaOH}$ (pretreatment) } \\
\hline Tekanan & 6 & 5 & 7 & 3 & 4 & 4 \\
\hline $\begin{array}{l}\text { Massa } \\
\text { padatan }\end{array}$ & 1164 & 1280 & 1030 & 1141,65 & 1141,65 & 1071,7 \\
\hline $\mathrm{pH}$ & 5 & 6 & 5 & 4 & 6 & 7 \\
\hline
\end{tabular}

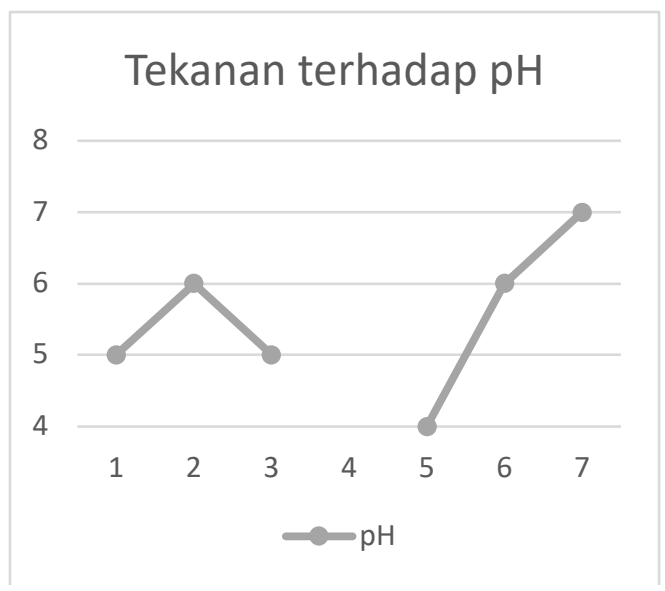

Gambar 3. Hubungan tekanan terhadap pH

Semakin besar tekanan maka terjadi kenaikan terhadap nilai $\mathrm{pH}$ pada $5 \% \mathrm{NaOH}$ dan $5 \%$ $\mathrm{NaOH}$ dengan pretreatment

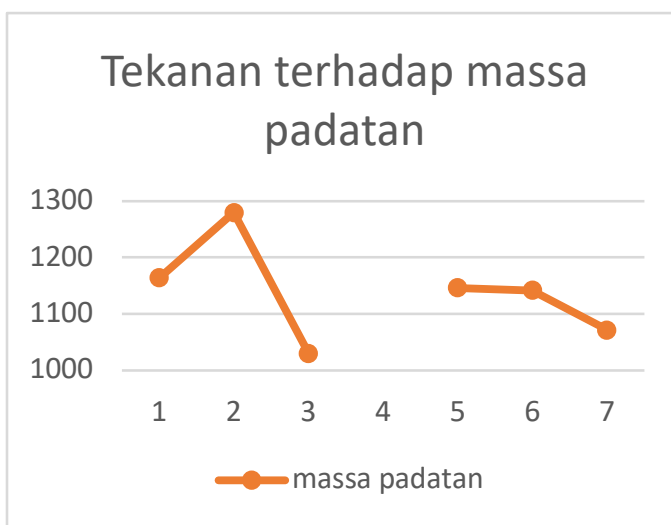

Gambar 4. Hubungan tekanan terhadap massa padatan

Semakin besar tekanan maka terjadi penurunan terhadap nilai massa padatan pada $5 \% \mathrm{NaOH}$ dan $5 \% \mathrm{NaOH}$ dengan pretreatment

Tabel 3. Hubungan antara suhu dan tekanan terhadap tekanan dan konsistensi

\begin{tabular}{|l|c|c|c|}
\hline \multirow{2}{*}{$\begin{array}{l}\text { suhu dan } \\
\text { tekanan }\end{array}$} & \multicolumn{3}{|c|}{$5 \% \mathrm{NaOH}$} \\
\cline { 2 - 4 } & 130 & 140 & 150 \\
\cline { 2 - 4 } & 6 & 5 & 7 \\
\hline tekanan & 8 & 6,4 & 9,6 \\
\hline konsitensi & 5,44 & 11,25 & 11,71 \\
\hline
\end{tabular}




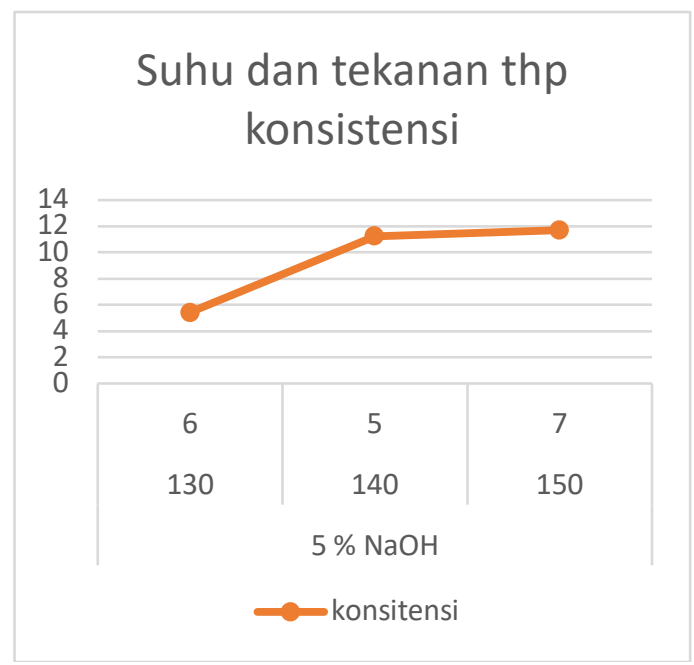

Semakin besar tekanan dan suhu maka terjadi peningkatan terhadap nilai konsistensi pada $5 \% \mathrm{NaOH}$

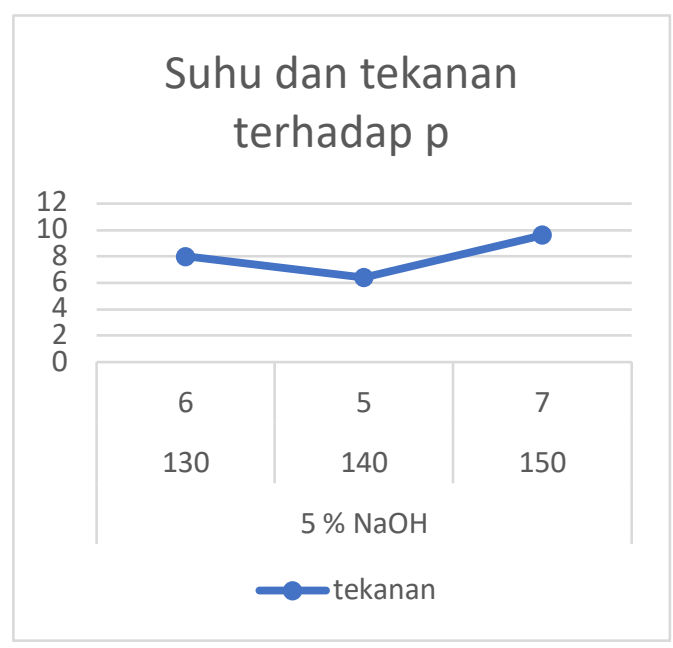

Semakin besar tekanan dan suhu maka terjadi peningkatan terhadap nilai massa padatan pada $5 \% \mathrm{NaOH}$

\section{Kesimpulan dan Saran}

\section{Kesimpulan}

1. Semakin besar suhu dan tekanan maka terjadi kenaikan terhadap nilai $\mathrm{pH}$ pada $5 \% \mathrm{NaOH}$ dan $5 \% \mathrm{NaOH}$ dengan pretreatment.

2. Semakin besar suhu dan tekanan maka terjadi penurunan terhadap massa padatan pada $5 \% \mathrm{NaOH}$ dan $5 \% \mathrm{NaOH}$ dengan pretreatment.

3. Semakin besar tekanan dan suhu maka terjadi peningkatan terhadap nilai konsistensi pada $5 \% \mathrm{NaOH}$.

4. Semakin besar tekanan dan suhu maka terjadi peningkatan terhadap nilai massa padatan pada $5 \% \mathrm{NaOH}$ tanpa pretreatment.

\section{Saran}

1. Pembuatan kertas kemasan hingga terbentuk produk kertas

\section{Ucapan terima kasih}

Ucapan terima kasih kepada Institut Teknologi dan Sains Bandung.

\section{Referensi}

Ati, N.H., Puji, R., Soenarto, N., and Leenawaty, L. 2006. "The Composition and The Content of Pigments from Some Dyeing Plant for Ikat Weaving in Timorrese Regency, East Nusa Tenggara". Indonesian Journal Chemistry 6(3):325-331.

Fagbemigun, Taiwo K., dkk. 2014. "Pulp and Paper-Making Potential of Cornhusk". LagosNigeria International Journal of Agri Science Vol. 4(4): 209-213.

Fellows,P.J. 2000. Food Processing Technology. Principles and Practice. 2nd Ed. Woodhead Publishing Ltd., Cambridge, England.

Haygreen, J. G dan J. L Bowyer. 1986. Hasil Hutan dan Ilmu Kayu Suatu Pengantar. Penerjemah Dr. Ir Sujipto A. Hadikusumo. Yogyakarta: Gadjah Mada University Press.

Miltz, J., 1992. Food Packaging in : Handbook of Food Engineering Heldman, D.R. and D.B.Lund (ed).Marcel Dekker, Inc., New York. Moldovan, B., David, L., Chişbora, C., and Cimpoiu, C. 2012. "Degradation Kinetics of Anthocyanins from European Cranberrybush (Viburnum opulus L.) Fruit Extracts. Effects of Temperature, $\mathrm{pH}$ and Storage Solvent". Journal Molecules 17(10):11655-11666.

Mustafa, Ria Mariana. 2006. Studi Efektifitas Bahan Pengawet Alami dalam Pengawetan Tahu. Bogor: ITB Press.

Mutiarawati, Aulina, dkk. 2013. Penetapan Kadar Pigmen Antosianin Daun Jati (Tectona grandis L.f) sebagai Bahan Pewarna Alami Makanan dengan Spektrofotometri UV-Vis. Surakarta: Universitas Setia Budi Press.

Ningsih, Eva Rahayu. 2012. Uji Kinerja Digester pada Proses Pulping Kulit Jagung dengan Variabel Suhu dan Waktu Pemasakan. Semarang: Universitas Diponegoro Press. 
Prasetyawati, Dwi Putri.2015.'Pemanfaatan Kulit Jagung dan Tongkol Jagung (Zea mays) Sebagai Bahan Dasar Pembuatan Kertas Seni Dengan Penambahan Natrium Hidroksida $(\mathrm{NaOH})$ dan Pewarna Alami”. Surakarta : Program Studi Pendidikan Biologi Fakultas Keguruan dan Ilmu Pendidikan : Universitas Muhammadiyah

Pujiarti, Rini, dan Kasmudjo. 2006. "Pengembangan Teknologi Pemanfaatan Hasil Hutan Berbasis Masyarakat". Banjarbaru: Universitas Lambung Mangkurat.
Rahmawati, Suci Siska. 2015. Pemanfaatan Limbah Bulu Ayam dan Kulit Kacang Tanah sebagai Bahan Pembuatan Kertas Seni dengan Penambahan $\mathrm{CaO}$ dan Pewarna Alami. Surakarta: UMS Press. 